\title{
Deletions of 11q22.3-q25 Are Associated with Atypical Lung Carcinoids and Poor Clinical Outcome
}

\author{
Dorian R.A. Swarts, ${ }^{*}$ Sandra M.H. Claessen, ${ }^{*}$ \\ Yvonne M.H. Jonkers, ${ }^{*}$ Robert-Jan van Suylen, ${ }^{\dagger}$ \\ Anne-Marie C. Dingemans, ${ }^{\ddagger}$ Wouter W. de Herder, ${ }^{\S}$ \\ Ronald R. de Krijger," Egbert F. Smit," \\ Frederik B.J.M. Thunnissen, ${ }^{*}$ \\ Cornelis A. Seldenrijk, ${ }^{\dagger+}$ Aryan Vink, ${ }^{+\ddagger}$ \\ Aurel Perren, ${ }^{\S \S}$ Frans C.S. Ramaekers, ${ }^{*}$ and \\ Ernst-Jan M. Speel ${ }^{\star \dagger}$

\begin{abstract}
From the Departments of Molecular Cell Biology, ${ }^{*}$ Pathology, ${ }^{\dagger}$

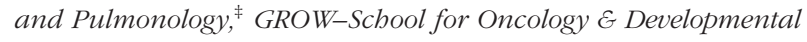
Biology, Maastricht University Medical Center, Maastricht, The Netherlands; the Departments of Internal Medicine $\$$ and Pathology, "Erasmus MC-University Medical Center, Rotterdam, The Netherlands; the Departments of Pulmonary Diseases" and Pathology, ${ }^{* *}$ Free University Medical Center, Amsterdam, The Netherlands; the Department of Pathology," St. Antonius Hospital, Nieuwegein, The Netherlands; the Department of Pathology, \# University Medical Center, Utrecht, The Netherlands; and the
\end{abstract} \\ Department of Pathology, ${ }^{\$ S}$ University of Bern, Bern, Switzerland
}

Carcinoids are slow-growing neuroendocrine tumors that, in the lung, can be subclassified as typical (TC) or atypical (AC). To identify genetic alterations that improve the prediction of prognosis, we investigated 34 carcinoid tumors of the lung (18 TCs, 15 ACs, and 1 unclassified) by using array comparative genomic hybridization (array CGH) on 3700 genomic bacterial artificial chromosome arrays (resolution $\leq 1 \mathrm{Mb}$ ). When comparing ACs with TCs, the data revealed: i) a significant difference in the average number of chromosome arms altered ( 9.6 versus 4.2 , respectively; $P=0.036$ ), with one subgroup of five ACs having more than 15 chromosome arms altered; ii) chromosomal changes in $30 \%$ of ACs or more with additions at $9 q(\geq 1 \mathrm{Mb})$ and losses at 1p, 2q, 10q, and 11q; and iii) 11q deletions in 8 of 15 ACs versus 1 of 18 TCs $(P=0.004)$, which was confirmed via fluorescence in situ hybridization. The four critical regions of interest in $45 \% \mathrm{ACs}$ or more comprised 11q14.1, 11q22.1-q22.3, 11q22.3-q23.2, and 11q24.2-q25, all telomeric of MEN1 at 11q13. Results were correlated with patient clinical data and long-term follow-up. Thus, there is a strong association of 11q22.3q25 loss with poorer prognosis, alone or in combi- nation with absence of $9 \mathrm{q} 34.11$ alterations $(P=$ 0.0022 and $P=0.00026$, respectively). (Am J Pathol 2011, 179:1129-1137; DOI: 10.1016/j.ajpath.2011.05.028)

Pulmonary carcinoids comprise a group of usually smoking-unrelated neuroendocrine tumors. Compared with poorly differentiated neuroendocrine tumors of the lung, ie, large-cell neuroendocrine carcinoma and small-cell lung cancer, carcinoids are well-differentiated and characterized by a low metastatic rate and a relatively favorable prognosis. On the basis of histopathologic features (number of mitoses and presence of necrosis), lung carcinoid tumors are classified as typical carcinoids (TCs) or atypical carcinoids (ACs), although classification is sometimes difficult and its reliability to predict disease outcome is variable. ${ }^{1}$ Compared with TCs, in general, ACs more often exhibit malignant behavior and are associated with a lower 5 -year survival rate $(61 \%$ to $88 \%$ and $92 \%$ to $100 \%$, respectively). ${ }^{2}$ Metastases will develop in $4 \%$ to $64 \%$ of patients with carcinoids (TCs, $4 \%$ to $14 \%$, and ACs, $35 \%$ to $64 \%$ ), usually in regional lymph nodes but also at distant sites including liver, bone, brain, subcutaneous tissue, and breast. ${ }^{2,3}$ Although most patients remain cancer-free within 5 years after surgery, there is no curative treatment available for metastatic disease.

A few studies have reported clinical and molecular factors associated with higher risk of developing metastases or with poor disease outcome. Clinical factors with prognostic value include size $3.5 \mathrm{~cm}$ or larger, mitotic index, degree of differentiation, presence of necrosis, co-secretion of peptides, and metastasis. ${ }^{4,5}$ Immunohis-

Supported by a grant from The Netherlands Foundation "De Drie Lichten", project number 2003/25 (Y.M.H.J.).

Accepted for publication May 6, 2011.

Supplemental material for this article can be found at http://ajp. amjpathol.org or at doi: 10.1016/j.ajpath.2011.05.028.

Current address of Y.M.H.J., Department of Medical Oncology, Radboud University, Nijmegen Medical Centre, Nijmegen, The Netherlands.

Address reprint requests to Dorian R.A. Swarts, M.Sc., Department of Molecular Cell Biology, UNS50-17, GROW-School for Oncology \& Developmental Biology, Maastricht University Medical Center, PO Box 616, 6200 MD Maastricht, The Netherlands. E-mail: d.swarts@maastrichtuniversity.nl. 
tochemistry on TC samples revealed that a high Ki-67 labeling index or up-regulation of the anti-apoptotic proteins $\mathrm{Bcl}-2$ and p53 were associated with metastatic disease and shorter survival time, whereas immunostaining for the adhesion molecule CD44 was associated with localized disease and lower mortality. ${ }^{6}$ An additional study of 121 pulmonary neuroendocrine tumors including 21 carcinoids demonstrated a shift to low Bax and high $\mathrm{BCl}-2$ expression in association with ACs, resulting in an unfavorable prognosis. ${ }^{7}$ The Rb pathway is more often modified in ACs than in TCs. P16 negativity was observed in $23 \%$ of ACs, compared with $9 \%$ of TCs, and absent staining for $\mathrm{pRb}$ in $21 \%$ of $\mathrm{ACs}$ and no TCs. ${ }^{8}$

Genomic alterations contribute to carcinogenesis by changing the expression levels of critical oncogenes and tumor-suppressor genes. In lung carcinoid tumorigenesis, few p53 and no EGFR or KRAS gene mutations have been detected, although the percentage of lung carcinoids expressing EGFR is higher in TCs than in ACs. ${ }^{9,10}$ Previous studies have primarily demonstrated multiple endocrine neoplasia type 1 (MEN1) gene mutations and/or chromosome $11 \mathrm{q}$ deletions. ${ }^{11-17}$ MEN1 is a syndrome in which an inherited mutation in the MEN1 gene, located at 11q13, predisposes to formation of multiple neuroendocrine tumors. Although formation of bronchial carcinoid tumors has been observed in only $2 \%$ of patients with MEN1, ${ }^{18}$ functional inactivation of menin, the MEN1 gene product, has been implicated in the tumorigenesis of sporadic lung carcinoids. In these bronchial carcinoids not associated with MEN1 syndrome, the frequency of loss of heterozygosity at $11 \mathrm{q}(36 \%)$ is higher than the somatic MEN1 mutation rate (18\%), pointing to the presence of other tumor-suppressor genes at this chromosome arm and/or involvement of epigenetic silencing mechanisms. ${ }^{12}$

To improve the discrimination between pulmonary carcinoid tumors with a favorable or poor prognosis and to identify critical genetic events in lung carcinoid tumorigenesis, we investigated 34 reclassified bronchial carcinoids by using array-based comparative genomic hybridization (array $\mathrm{CGH}$ ) with a resolution of $\leq 1 \mathrm{Mb}$ (megabase). Fluorescence in situ hybridization (FISH) was used to determine chromosome copy numbers and to validate array $\mathrm{CGH}$ data. Furthermore, the array $\mathrm{CGH}$ data were correlated with available histopathologic data and long-term clinical follow-up.

\section{Materials and Methods}

\section{Tumor Material, Histopathologic Analysis, and Clinical Data Collection}

Both frozen and formalin-fixed, paraffin-embedded (FFPE) tumor material were collected from 34 patients [14 male and 20 female; mean age, 50 years (age range, 16 to 83 years)] with lung carcinoid tumors from the archives of the Departments of Pathology of our institutions. Patient material was used according to the Code for Proper Secondary Use of Human Tissue (Federation of Medical Scientific Societies, The Netherlands; 2003). All material was reclassified by two experienced pathologists (R.-J.v.S. and F.B.J.M.T.) on the basis of histopathologic features according to the most recent World Health Organization classification, ${ }^{1}$ resulting in 18 TCs [no necrosis and mitotic index less than 2 per 10 high-power fields; mean patient age, 47 years (age range, 19 to 68 years)] and 15 ACs (necrosis and/or mitotic index between 2 and 10 per 10 high-power fields; mean patient age, 56 years (age range, 22 to 83 years)]. One carcinoid tumor could not be reliably classified. In earlier studies, eight patients underwent conventional $\mathrm{CGH}^{17}$ and MEN1 mutation analysis. ${ }^{12}$ Follow-up data were collected from 33 of 34 patients, and ranged from 3 to 25 years (median, 101 months). Clinical data and tumor characteristics are given in Supplemental Table S1 (available at $h$ ttp://ajp.amjpathol.org).

\section{Array CGH Analysis}

DNA was extracted from the frozen and FFPE tissues with at least $70 \%$ tumor cells using the DNeasy Blood and Tissue Kit (Qiagen GmbH, Hilden, Germany). Array CGH was performed on microarrays containing $3700 \mathrm{FISH}$ verified bacterial artificial chromosome (BAC) clones at a resolution of $\leq 1 \mathrm{Mb} .{ }^{19}$ Genomic DNA labeling procedures were performed as described elsewhere, using $500 \mathrm{ng}$ tumor and reference DNA each in a randomly primed labeling procedure. ${ }^{20}$ These Cy3-labeled tumor and Cy5-labeled normal reference DNA samples were mixed together with $120 \mu \mathrm{g}$ Cot-1 DNA (F. Hoffman-La Roche AG, Basel Switzerland) and co-precipitated for at least 30 minutes in ethanol at $-80^{\circ} \mathrm{C}$. Pellets were airdried and resolved in a total volume of $130 \mu \mathrm{L}$ hybridization mixture containing $50 \%$ formamide, $10 \%$ dextran sulfate, $4 \%$ SDS, $100 \mu$ g yeast transfer RNA, and 2X saline sodium citrate. This probe mixture was denatured for 5 minutes at $80^{\circ} \mathrm{C}$ and pre-annealed for 30 minutes at $37^{\circ} \mathrm{C}$. After pre-annealing, the sample was applied to the BAC array using the HS4800 hybridization station (Tecan Group Ltd., Männedorf, Switzerland). After hybridization for 23 hours, the arrays were rinsed with $40 \%$ formamide in $2 \mathrm{X}$ saline sodium citrate at $47^{\circ} \mathrm{C}$, followed by $2 \mathrm{X}$ saline sodium citrate containing $0.1 \%$ SDS at $47^{\circ} \mathrm{C}$ and $0.1 \mathrm{X}$ saline sodium citrate at $30^{\circ} \mathrm{C}$. The slides were dried using liquid nitrogen.

Fluorescence images of the arrays were acquired using a Scan Array Express scanner (PerkinElmer Life and Analytical Sciences BV, Groningen, The Netherlands) and analyzed using GenePix Pro 6.0 (Axon Instruments, Inc, Foster City, CA) as described previously. ${ }^{20}$ To obtain a genomic copy number ratio for each spot, the median local background was subtracted from the median pixel intensity of both dyes. Data normalization was performed for each microarray subgrid, and median fluorescence values per clone were determined. All data were $\log _{2}-$ transformed and interpreted as follows: the fluorescence signal intensity of the hybridized DNA at a certain BAC clone was considered significantly altered when demonstrating a change in the $\log _{2}$ ratio $\geq 0.2$ (frozen tissue) or $\geq 0.3$ (paraffin) when comparing the tumor with the normal reference tissue. For each corresponding profile, alterations in chromosomal regions were determined us- 
ing two different procedures. First, regions of gain and/or loss $\geq 10 \mathrm{Mb}$ were listed. These correspond to alterations that can also be detected by using conventional CGH (see Supplemental Table S1 at http://ajp.amjpathol. org). ${ }^{21}$ Second, to analyze smaller regions of interest, altered regions $\geq 1 \mathrm{Mb}$ were determined. These comprise at least three adjacent BAC clones with significantly altered fluorescence signals, allowing a maximum of two not significantly changed signals in between two of these altered regions. ${ }^{20}$ Chromosomal instability $(\mathrm{CIN})$ was defined as the presence of at least one alteration $\geq 10 \mathrm{Mb}$ in a minimum of eight chromosome arms, as described previously. ${ }^{22}$ Amplifications were defined as regions containing two or more adjacent signals demonstrating a change of $\log _{2}$ chromosome copy number ratio $\geq 1.0$ ( $\geq 1.5$ for paraffin). All mapping information about clone locations, cytogenetic bands, and genomic content was retrieved from the University of California at Santa Cruz Genome Browser (version hg19; UCSC Genome Bioinformatics Group, Santa Cruz, CA). ${ }^{23}$ All raw array CGH data are available in the ArrayExpress database (http:// www.ebi.ac.uk/arrayexpress) under accession number E-MEXP-3145.

\section{DNA Copy Number Analysis Using FISH}

FISH with centromere-specific probes for chromosomes $1,3,7$, and 11 was performed on $4-\mu \mathrm{m}$ tumor sections to obtain an indication of the ploidy at $\log _{2}=0$ and to validate chromosome copy number alterations detected by using array $\mathrm{CGH}$. In addition, deletions of $11 \mathrm{q}$ were validated in five cases using FISH-mapped cosmid probes specific for the MEN1 gene locus at $11 q_{13^{24}}$ and loci telomeric of MEN1 at $11 \mathrm{q} 13$ (clone $\mathrm{CKO}^{25} 4^{25}$ ), 11q13.4-q21 (clone cCl11-270), 11q22.2 (clone U836), and 11qter (clone cCl11-314 ${ }^{26}$ ), in all cases together with a centromere 11-specific probe. (Probes were kindly provided by J. Hoovers, Academic Medical Center Amsterdam, and A. Geurts van Kessel, Radboud University Nijmegen Medical Center, Nijmegen, The Netherlands). Amplification of 8q24.21 was analyzed using the Vysis LSI MYC Dual Color, Break Apart Rearrangement Probe (Abbott Molecular, Abbott Laboratories, Abbott Park, IL). FISH on paraffin-embedded tissue sections using centromere probes and touch preparations using both centromere and cosmid probes was performed as described previously, ${ }^{17}$ with modification of the $85 \%$ formic acid $/ 3 \%$ $\mathrm{H}_{2} \mathrm{O}_{2}$ step from 20 to 5 minutes for the paraffin sections. Probe visualization, nuclear counterstaining, signal scoring, and evaluation were performed as described previously. ${ }^{17}$ For each tumor hybridization, signals of 100 interphase nuclei were scored.

\section{Immunohistochemistry}

Immunohistochemical protein staining on $4-\mu \mathrm{m}$ thick FFPE and frozen sections was performed for Bcl-2 (clone 124; Dako A/S, Glostrup, Denmark), p53 (clone DO-7; Dako A/S), and pRb (clone LM95.1; Oncogene Research Products, La Jolla, CA) as follows. To retrieve epitopes, FFPE sections were first deparaffinized and subsequently microwave heated for $3 \times 5$ minutes and cooled down in between for 5 minutes at room temperature in 0.01 $\mathrm{mmol} / \mathrm{L}$ citrate buffer ( $\mathrm{pH}$ 6.0) for $\mathrm{p} 53$ or for 20 minutes in $0.1 \mathrm{mmol} / \mathrm{L}$ Tris-EDTA buffer ( $\mathrm{pH}$ 9.0) for Bcl-2 and pRb. Endogenous peroxidase activity of the tissue was inhibited by incubation with $0.3 \%$ to $2 \% \mathrm{H}_{2} \mathrm{O}_{2}$ in methanol for 30 minutes. For $\mathrm{Bcl}-2$ and $\mathrm{p} 53$ staining, frozen sections were fixed for 10 minutes in methanol $\left(-20^{\circ} \mathrm{C}\right)$. For $\mathrm{pRb}$ staining, frozen sections were fixed for 15 minutes in $4 \%$ formaldehyde/0.1\% Triton X-100 in PBS. Endogenous peroxidase activity was blocked with $0.3 \% \mathrm{H}_{2} \mathrm{O}_{2}$ in PBS for 20 minutes. Both frozen and FFPE sections were blocked with $3 \%$ bovine serum albumin in PBS before incubation with the primary antibody. The antibodies against p53 and Bcl-2 were used at a dilution of 1:50, and the $\mathrm{pRb}$ antibody was diluted to 1:33. Antibodies were diluted in $1 \%$ bovine serum albumin in PBS, and incubation was performed overnight at $4^{\circ} \mathrm{C}$. As a secondary antibody, PowerVision Poly-HRP goat anti-mouse/antirabbit/anti-rat IgG (Immunologic, Duiven, The Netherlands) was used. Peroxidase activity was detected using $0.5 \mathrm{mg} / \mathrm{mL}$ diaminobenzidine $/ 2 \% \mathrm{H}_{2} \mathrm{O}_{2}$. Sections were counterstained with hematoxylin and mounted in Entellan (Merck KGaA, Darmstadt, Germany). Staining intensities were graded as follows: for $\mathrm{Bcl}-2,<1 \%$ positive staining; ,$+ 1 \%$ to $5 \%$ positive staining;,$++ 5 \%$ to $20 \%$ positive staining; and,$+++>20 \%$ positive staining; for p53, $0 \%$ positive staining;,$+<5 \%$ positive staining;,$++ 5 \%$ to $20 \%$ positive staining; and,$+++>20 \%$ positive staining; and for $\mathrm{pRb},<1 \%$ positive staining;,$+ 1 \%$ to $10 \%$ positive staining;,$++ 10 \%$ to $20 \%$ positive staining; and,$+++>$ $20 \%$ positive staining.

\section{Statistical Analysis}

Possible correlations between clinical data and chromosomal alterations were determined using SPSS for Windows (version 15.0; SPSS Inc., Chicago, IL). Associations between the number of genomic alterations and histopathologic classification of ACs or TCs were analyzed using Student's t-test. Associations between sex, diameter, classification, protein expression, and specific chromosomal alterations, and follow-up were analyzed using the $\chi^{2}$ test or Fisher's exact test, when appropriate. Correlation of age or number of alterations with clinical follow-up were determined using log regression analysis. Survival curves were created using the Kaplan-Meier method. The log-rank test was used to test for differences between subgroups. $P \leq 0.05$ (two-sided) was considered statistically significant.

\section{Results}

\section{Subsets of ACs Show Either Low or High Numbers of Chromosomal Alterations}

Genomic DNA isolated from 34 bronchial carcinoid tumors (15 ACs, 18 TCs, and 1 unclassified) was analyzed by using array $\mathrm{CGH}$ for the presence of chromosomal copy number changes. Representative array CGH pro- 
A

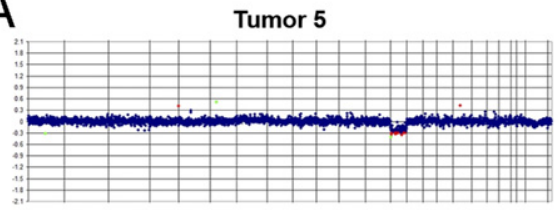

Tumor 27

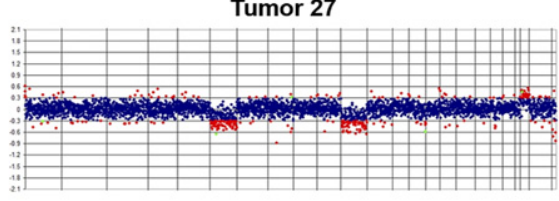

Tumor 29

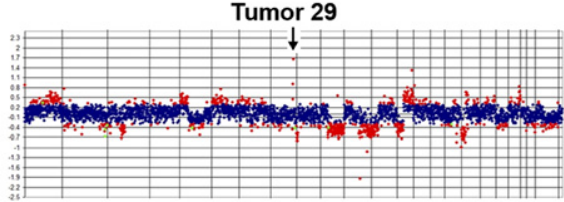

D

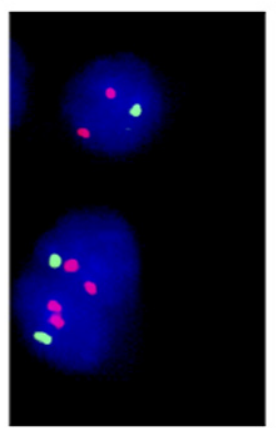

$E$

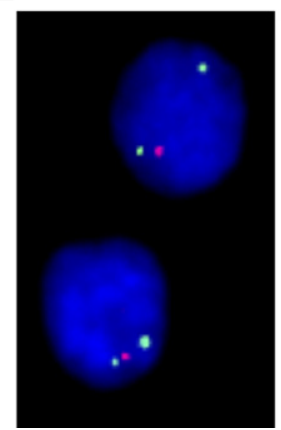

B
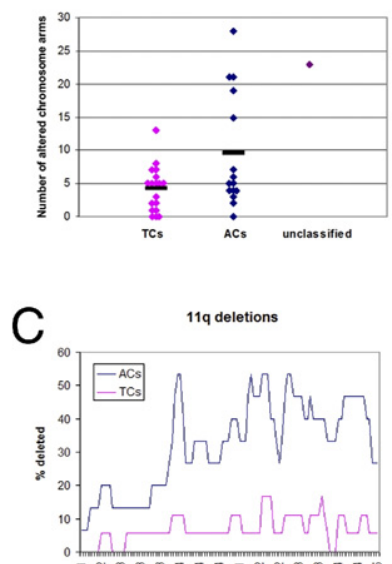

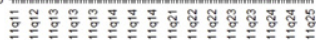

$\mathrm{F}$

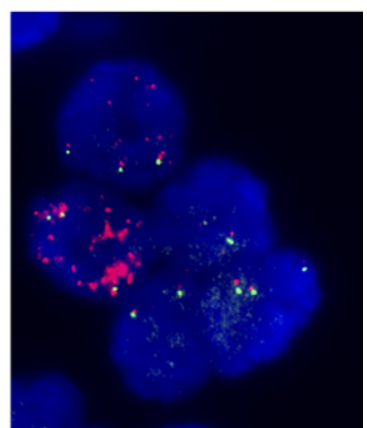

Figure 1. Analysis of chromosomal alterations in lung carcinoid tumors. A: Representative array CGH profiles of a typical carcinoid (TC) and two atypical carcinoids (ACs). Case 5 (TC; see Supplemental Table $\mathrm{S} 1$ at http://ajp. ampathol.org) demonstrates deletion of chromosome 13q; case $27(\mathrm{AC})$, deletion ( $\geq 10 \mathrm{Mb}$ ) of chromosomes $6 \mathrm{pq}$ and $11 \mathrm{pq}$ and gain of chromosome 22pq; and case 29 (AC), gain of chromosomes 1q, 5p, 6p, 13q, 18q, and 20q and loss of chromosomes 3p, 5q, 8p, 9q, 10q, 11q, 13p, 17p, and Xq Furthermore, case 29 exhibits amplification at $8 \mathrm{q} 24$, the region containing the oncogene $M Y C$ (arrow). B: Difference in number of chromosome arms containing at least one altered region $\geq 10 \mathrm{Mb}$ per tumor between TCs and ACs $(4.2 \pm 3.4$ versus $9.5 \pm 8.7$, respectively; $P=0.036$ ). Black bar indicates the mean number of altered chromosome arms. C: Graph shows frequency of deletion of specific regions at chromosome arm 11q comparing ACs (blue) with TCs (red). D-F: Fluorescence in situ hybridization (original magnification $\times 630)$ of $(\mathbf{D})$ centromere 1 (green) and centromere 7 (red) in case 13 (see Supplemental Table S1 at http://ajp. amjpathol.org) exhibiting two copies of chromosome 7 and one copy of chromosome 1. E: An 11q probe located at the MEN1 locus at 11q13 (green) and a probe located at 11q13.4-21 (red) in case 23 (see Supplemental Table S1 at bttp://ajp.amipathol.org), showing loss at $11 \mathrm{q}$ telomeric of the MEN1 gene. F: Vysis LSI MYC Dual Color, Break Apart Rearrangement Probe in case 29 (see Supplemental Table S1 at http://ajp.amipathol.org) shows three copies for the Spectrum Green-labeled probe target located 1.6 Mb telomeric of MYC (green) and three copies for the Spectrum Orangelabeled probe target $120 \mathrm{~kb}$ centromeric of $M Y C$ in approximately $75 \%$ of the nuclei (red). Multiple copies of the Spectrum Orange-labeled probe target were observed in the remaining $25 \%$ of nuclei, indicating amplification of this region. files of one TC and two ACs are shown in Figure 1A. Chromosomal alterations $\geq 10 \mathrm{Mb}$ were observed in 14 of 18 TCs and 14 of 15 ACs (see Supplemental Table S1 at http://ajp.amjpathol.org). A maximum of 28 altered chromosome arms (with at least one region that was $\geq 10 \mathrm{Mb}$ ) was identified, with a mean \pm SD of $7.1 \pm 6.9$ for the entire group of carcinoids. ACs exhibited a mean number of altered chromosome arms of $9.6 \pm 8.7$, whereas TCs demonstrated significantly fewer alterations, ie, $4.2 \pm 3.4$ $(P=0.036$, Student's $t$-test; Figure 1B). Of the group of ACs, 8 of 15 harbored few or no chromosome arms with copy number changes $(3.7 \pm 2.4)$, similar to TCs, whereas the remaining cases exhibited higher numbers of altered arms $(20.0 \pm 5.0)$, indicating CIN.

\section{1q Deletions Are the Most Frequent Aberrations in Pulmonary Carcinoids and Are Strongly Associated with ACs}

Insofar as alterations $\geq 10 \mathrm{Mb}, 8$ of $15 \mathrm{ACs}$ (53\%) exhibited a deletion in chromosome 11q, whereas a deletion of this region was observed in only 1 of 18 TCs $(P=0.004$; Fisher's exact test; Figure 1C). Alterations in other chromosome arms were not present significantly more often in ACs than in TCs (data not shown). Significant chromosomal alterations ( $\geq 1 \mathrm{Mb}$, three or more subsequent clones) detected in greater than $30 \%$ of $\mathrm{ACs}$ are given in
Table 1. The size of altered regions ranged from 2.80 to $57.91 \mathrm{Mb}$, and the most frequent alteration in ACs was deletion of 11q13.5-qter. Not the region harboring the tumor-suppressor gene MEN1 but four regions located telomeric of $11 q 13$ were most often deleted: 11q14, 11q22.1-q22.3, 11q22.3-q23.2, and 11q24.2-q25 (Figure 1C; Table 2). Only 2 of 34 lung carcinoids demonstrated loss of the 11 q13 region harboring MEN1, in both cases together with a MEN1 mutation [case 21 (see Supplemental Table S1 at http://ajp.amjpathol.org), D172V, exon 3; and case 24 (see Supplemental Table S1 at http://ajp. amjpathol.org), 434ins29, exon 2], as reported previously. ${ }^{12}$ Also, five additional cases $(10,17,18,20$, and 23) in which no MEN1 mutations were observed did not exhibit deletion of the MEN1 locus at 11q13. Other frequent alterations in ACs included gains on chromosomes $8,9 q$, and 17 and deletions on chromosomes $1 p, 2 q$, 10q, and 22q13.2 (Table 1; see also Supplemental Table S2 at http://ajp.amjpathol.org). Gains on chromosomes 8 and 9 and losses on chromosome $22 q$ were most often observed in ACs without deletion of $11 q$ (data not shown).

Amplifications were observed in two ACs. Case 30 (see Supplemental Table S1 at http://ajp.amjpathol.org) demonstrated amplifications at chromosomes 8q21.13 and 17q23.23-q24.2, and case 29 at 8q24.21 (Figure $1 \mathrm{~A})$. Of note, both patients had an aggressive tumor with 
Table 1. Chromosomal Alterations ( $\geq 1 \mathrm{Mb}$ Regions in at Least $30 \%$ of ACs)

\begin{tabular}{|c|c|c|c|c|}
\hline Cytogenetic region & Type & Size (Mb) & Frequency (\%) & $\begin{array}{l}\text { Survival analysis } \\
\text { (Log rank } P \text { value) }\end{array}$ \\
\hline 1p31.1 & Loss & 3.75 & 33 & NS \\
\hline 1p21.2-p21.3 & Loss & 2.80 & 38 & NS \\
\hline $2 q 22.1-q 22.3$ & Loss & 9.22 & 33 & NS \\
\hline $9 q 33.3-q 34.13$ & Gain & 5.71 & 33 & $0.044(\uparrow)$ \\
\hline 10q21.2-q21.3 & Loss & 6.59 & 33 & NS \\
\hline 11q13.5-q25 & Loss & 57.91 & 42 & \\
\hline $11 q 14.1^{*}$ & Loss & 3.27 & 48 & NS \\
\hline $11 q 22.1-q 22.3^{*}$ & Loss & 5.34 & 50 & $0.0070(\downarrow)$ \\
\hline $11 \mathrm{q} 22.3-\mathrm{q} 23.2^{*}$ & Loss & 7.10 & 49 & $0.0022(\downarrow)$ \\
\hline 11q24.2-q25* & Loss & 9.02 & 47 & $0.0028(\downarrow)$ \\
\hline
\end{tabular}

*These losses occurred in $45 \%$ or more of ACs.

$\uparrow$, positive effect on survival; $\downarrow$, negative effect on survival; AC, atypical carcinoid; NS, not significant.

$11 \mathrm{q}$ loss, and died within 3 years after diagnosis. Alterations in TCs were randomly distributed over the genome, and reached a threshold of only $25 \%$ or greater in five chromosomal regions (see Supplemental Table S2 at http://ajp.amjpathol.org).

\section{Bronchial Carcinoids Show (Near) Diploid DNA Content}

To assess the chromosome copy number at $\log _{2}=0$ in the array $\mathrm{CGH}$ profiles of lung carcinoid tumors, FISH was performed using probes for chromosomes 1, 3, 7, and 11 centromeres. All carcinoids were disomic for at least three chromosome targets, indicating a (near) diploid DNA index. FISH was also used for validation of the array CGH results given in Supplemental Table S1 (available at http://ajp.amjpathol.org), and confirmed loss of centromere 1 in cases 12 and 32 (Figure 1D), loss of centromere 11 in case 27 , and gains of centromere 7 in cases 15, 24, and 34. In five cases, $11 \mathrm{q}$ deletion was confirmed using FISH with cosmid probes (Table 2; Figure 1E).

Amplification of the $8 q 24.21$ region in case 29 (see Supplemental Table S1 at http://ajp.amjpathol.org) was confirmed using an MYC dual-color translocation probe. All nuclei exhibited three copies of the Spectrum Greenlabeled probe target located $1.6 \mathrm{Mb}$ telomeric of MYC (alias c-myc). In approximately $75 \%$ of nuclei, three copies were also observed with the Spectrum Orange-labeled probe target $120 \mathrm{~kb}$ centromeric of MYC. However, the remaining $25 \%$ of nuclei exhibited multiple copies of this target, indicating amplification (Figure 1F). This indi- cates that MYC was involved in the amplification, with the breakpoint of this amplification telomeric of the gene.

\section{Deletion of 11q22.3-q25 Is Associated with Poor Clinical Outcome}

Analysis of 10-year overall survival demonstrated a significant difference between TCs and ACs (Figure 2), in agreement with the literature. ${ }^{1,2}$ The subgroup of ACs harboring CIN demonstrated no correlation with favorable or poor prognosis (data not shown). Patients with loss of 11q22.3-q23.2 (Figure 3A) or 11q24.2-q25 had a significantly worse prognosis than did patients without loss of $11 \mathrm{q}$, both in the total group of carcinoids $(P=$ 0.0022 for $11 \mathrm{q} 22.3-\mathrm{q} 23.2$, and $P=0.0028$ for $11 \mathrm{q} 24.2-$ q25) and within ACs ( $P=0.033$ for both deletions) (Figure $3 \mathrm{~B})$. Deletion of the two more centromeric regions demonstrated a weaker (11q22.1-q22.3; $P=0.007$ ) or no (11q14.1) correlation with poor prognosis. Gain of 9q34.11 was associated with a favorable prognosis, both in the total group of carcinoids ( $P=0.044$; Figure $3 C$ ) and within ACs $(P=0.023$; Figure 3D). A combination of loss of 11q22.3-q23.2 or 11q24.2-q25 in the absence of alterations in chromosome $9 \mathrm{q} 34.11$ was the best predictor of poorer outcome, both in the total group of carcinoids $(P=0.00026$; Figure $3 \mathrm{E})$ and within the group of ACs $(P=0.018$; Figure 3F). Deletion of 11q22.3-q23.2 or 11 q24.2-q25 without 9q34.11 gain $(P=0.026)$ was also correlated with a higher risk of distant metastases. In addition, larger tumor diameter $(\geq 3.5 \mathrm{~cm} ; P=0.024)$ correlated with metastases, in agreement with earlier studies. ${ }^{4,5}$ There was a trend toward an association be-

Table 2. Copy Number Evaluation of 11q-Specific Targets in Lung Carcinoid Tumors Using FISH with Cosmid Probes

\begin{tabular}{cccccc}
\hline Tumor & $11 C^{*}$ & $11 q 13(M E N 1)$ & $11 q 13$ & $11 q 13.4-21$ & 1 1 q23.3-24.1 \\
\hline 12 & $2^{\dagger}$ & 2 & 2 & 1 & NA \\
22 & 2 & 2 & 2 & 1 & 1 \\
23 & 2 & 1 & 1 & 1 & 1 \\
25 & 2 & 2 & 1 & 1 & 1 \\
26 & 2 & 1 & 1 & 1 \\
\hline
\end{tabular}

${ }^{*}$ Centromere of chromosome 11.

${ }^{\dagger}$ Maximal number of centromere copies per nucleus in $20 \%$ or more of nuclei in the tumor.

NA, not analyzed. 


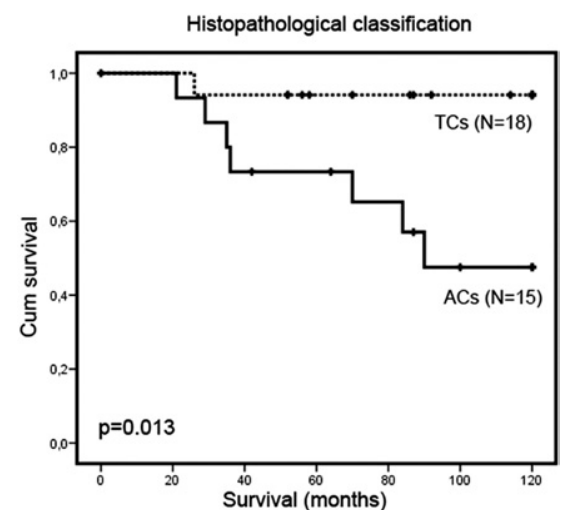

Figure 2. Survival analysis based on histopathologic classification. KaplanMeier curve comparing overall 10-year survival of typical carcinoids (TCs; dotted line) and atypical carcinoids (ACs; solid line). +, Censored cases.

tween deletion of $11 q$ and larger diameter $(P=0.058)$. No relation between smoking and our clinical or array CGH data was observed.

\section{Presence of Tumor Marker Proteins in Carcinoids}

Immunohistochemistry was performed for Bcl-2, p53, and $\mathrm{pRb}$, markers described as having potential prognostic significance in neuroendocrine lung tumors. ${ }^{6-8}$ Positivity for Bcl-2 was observed in 23 of 30 cases, for p53 in 5 of 31 cases, and for $\mathrm{pRb}$ in 23 of 29 cases (see Supplemental Table S1 at http://ajp.amjpathol.org). Positive staining for these markers was not associated with histopathologic findings, survival, or metastasis, although low $\mathrm{pRb}$ expression ( $<10 \%$ positive nuclei) was correlated with deletions of 11q14 ( $P=0.029), 11 q 22.1-q 22.3(P=$ $0.0084)$, and 11q22.3-q23.2 ( $P=0.018)$.

\section{Discussion}

This is the first report to provide a genome wide array $\mathrm{CGH}$ analysis of chromosomal alterations in TCs and ACs at a resolution of $\leq 1 \mathrm{Mb}$. Furthermore, the most frequently observed genomic alterations were correlated with long-term clinical follow-up data. We observed that deletion of 11q22.3-q25 is associated with ACs, and more particularly with a poor clinical outcome in this subgroup of carcinoid tumors. The combination of this deleted region with absence of 9q34.11 alterations further improves the predictive value of this assay. No correlations with clinical outcome were observed for the frequently observed deletion of $11 q 14$, a region with few annotated functional genes; presence of CIN; or protein expression of $\mathrm{Bcl}-2$, p53, or pRb.

\section{1q22.3-q25 versus 11q13 (MEN1) in Carcinogenesis of Pulmonary Carcinoids}

In the present study, deletions of 11q14, 11q22.1-q22.3, 11q22.3-q23.2, and 11q24.2-q25 were the most fre- quently ( $\geq 48 \%$ ) observed alterations in ACs. These regions are located telomeric of the MEN1 gene positioned at $11 \mathrm{q} 13$, which was previously reported to be the most critical region of loss in bronchial carcinoids and several other neuroendocrine tumors. ${ }^{27}$ Inactivation of MEN1 has been proposed as an early genetic event in the carcinogenesis of lung carcinoids. ${ }^{11,12}$ Deletion of 11 q13 was observed in only two cases, both with a mutation of the MEN1 gene. Much higher frequency of 11q13 loss has been published previously, ${ }^{28}$ and we cannot exclude a microdeletion of this locus because MEN1 was not covered by the probe targets on our CGH array. However, the absence of MEN1 gene mutations in cases without 11 q13 deletion makes this possibility unlikely. Together, these observations imply that other mechanisms of tumorigenesis exist in pulmonary carcinoids not associated with MEN1 gene aberrations, including involvement of candidate genes in the 11q22.3-q25 region.

Conflicting results have been published on the frequency of $11 \mathrm{q}$ loss in lung carcinoids in conventional CGH or loss of heterozygosity studies. ${ }^{13,14,16,29,30}$ Frequency ranged from $0 \%$ to $56 \%$ (mean, $34 \%$ ) in TCs, and from $10 \%$ to $73 \%$ (mean, $50 \%$ ) in ACs. These differences are most likely due to either the use of older classification
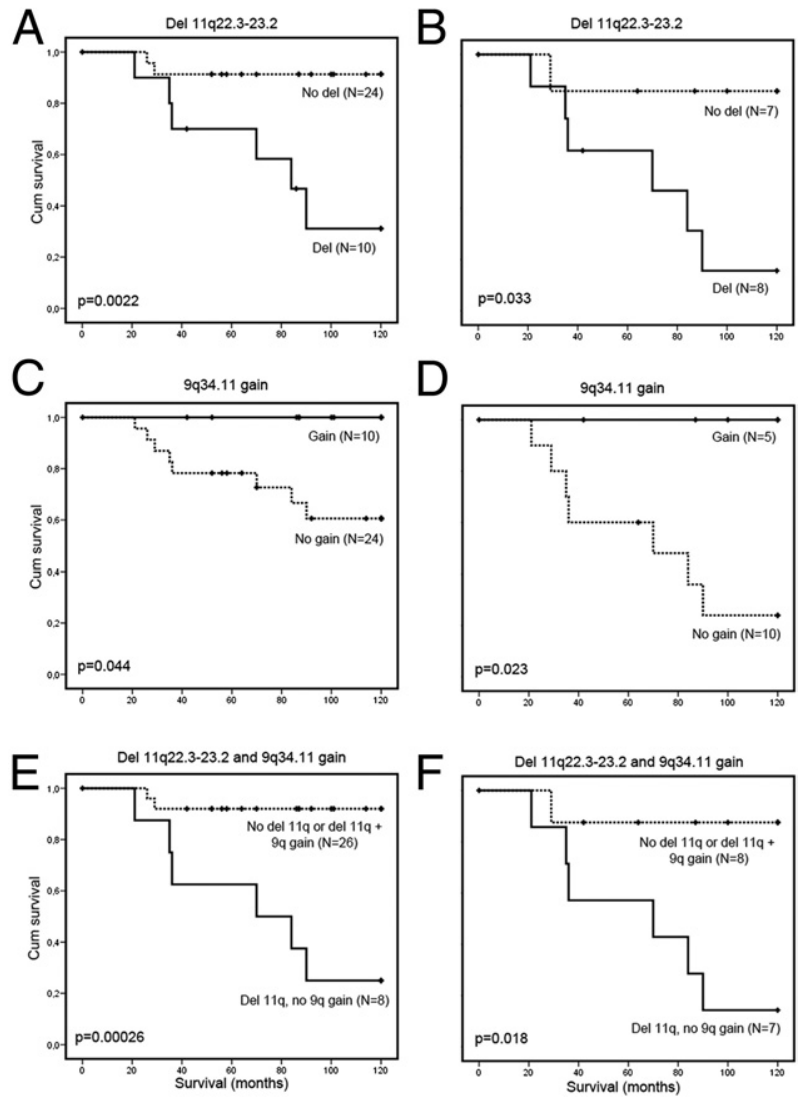

Figure 3. Survival analysis based on array CGH data. Kaplan-Meier curve comparing overall 10-year survival of all carcinoids (A) and atypical carcinoids (ACs) (B) with (solid line) or without (dotted line) 11q22.3-q23.2 deletion; all carcinoids (C) and ACs (D) with (solid line) or without (dotted line) 9q34.11 gain; all carcinoids (E) and ACs (F) with 11q22.3-q23.2 deletion but no 9q34.11 gain (solid line) compared with cases without 11q22.3-q23.2 deletion or with 11q22.3-q23.2 deletion in the presence of 9q34.11 gain (dotted line). + , Censored cases. 
systems $\mathrm{s}^{31}$ or differences in the ratio between TCs and ACs included in the respective studies. In two previous array CGH studies of 16 lung carcinoids ${ }^{15}$ and 19 lung carcinoids, ${ }^{32}$ respectively, a critical region of loss on chromosome 11q could not be specified and correlation with patient survival could not be provided.

\section{Deletion of 11q22.3-q25 Rather Than CIN Is Correlated with Poor Prognosis}

In the present study, deletion of the telomeric part of chromosome 11q, ie, 11q22.3-q25, was strongly correlated with poor prognosis. Gain of chromosome 9q34.11 was associated with a favorable outcome. Deletion of $11 \mathrm{q}$ has also been identified in other neuroendocrine tumors in association with metastatic disease including neuroblastomas (11q23) ${ }^{33,34}$ and insulinomas (11q24.1). ${ }^{20}$ Loss of 11q22.3-q23.2 or 11q24.2-q25 in the absence of 9q34.11 alterations was the best predictor of poor prognosis, both for the total group of tumors and within ACs. Protein expression of three well-described genetic markers (Bcl-2, p53, and pRb) was not correlated with disease outcome in our tumor series, which underlines the prognostic importance of $11 \mathrm{q}$ deletion.

Prognosis in patients with ACs was significantly worse than in patients with TCs, consistent with the literature, ${ }^{2}$ although the discrimination of lung carcinoids with a favorable and poor prognosis could be strongly improved using the above-mentioned genetic biomarkers.

We observed that a subset of ACs demonstrated CIN, an accumulation of chromosomal gains and losses, which is often induced by shortening of telomeres to a critical length. Two of our cases with CIN demonstrated loss of more than 10 telomeric regions, established because six consecutive telomeric BAC clones exhibited loss. In addition, CIN may be present more frequently in ACs and metastasized carcinoids than in TCs. ${ }^{30}$ However, the tumors that demonstrated CIN described by those authors exhibited lower numbers of alterations than did those in the underlying study, in which a cutoff of at least one alteration $\geq 10 \mathrm{Mb}$ in 8 or more chromosome arms was used to indicate CIN. Nevertheless, their results support our finding that ACs are associated with a higher number of chromosomal alterations. Furthermore, none of the tumors included in their study demonstrated distant metastases, and the two tumors with the most extensive lymph node metastases both exhibited deletion of 11q. Thus, not the total number of chromosomal alterations but 11q22.3-q25 status is strongly correlated with the malignant potential of lung carcinoids.

\section{Candidate Genes on 11q22.3-q25}

Putative tumor-suppressor genes or suppressors of tumor progression are located at 11q22.3-q23.3 and 11q24.2-q25. Candidates comprise genes that are frequently hypermethylated and silenced in other lung tumors, eg, the angiogenesis inhibitor ADAMTS- ${ }^{35}$ and the cell adhesion molecule $O P C M L^{36-38}$ in non-small cell lung cancer, both located at 11q25. Furthermore, genes involved in the carcinogenesis of other neuroendocrine tumors might have a role. For example, there may be involvement of genes located at $11 \mathrm{q} 23$ such as SDHD, ${ }^{39}$ reported to be mutated in sporadic parasympathetic paragangliomas; CADM1, ${ }^{40}$ down-regulated in neuroblastomas and significantly associated with an unfavorable outcome; and $A T M^{41}$ and the menin interacter $M L L$, respectively reported to be mutated or translocated in leukemia. MLL encodes a protein that, together with menin, resides in a complex that methylates histone 3 lysine 4 , an epigenetic mark associated with gene activation. ${ }^{42}$ The menin-MLL complex activates transcription of the cyclin-dependent kinase inhibitors $p 18, p 21$, and p27 and several homeobox genes, eg, Hoxa9, Hoxc6, and Hoxc8. ${ }^{42-45}$ Because bronchial carcinoids are characterized by low mitotic activity, escape from apoptosis rather than promotion of proliferation might have an important role in their carcinogenesis. A cluster of caspases and genes encoding other caspase activation and recruitment domain proteins are located at 11q22.2q23. ${ }^{46-50}$ Although their exact function is currently unknown, their presence at this region may indicate involvement in suppressing apoptosis in pulmonary carcinoids in addition to the previously reported higher expression of anti-apoptotic $\mathrm{Bcl}-2$ and lower expression of pro-apoptotic Bax protein in (atypical) carcinoids. ${ }^{7,51}$

\section{Mechanisms of Carcinogenesis in Pulmonary Carcinoids}

Apart from MEN1-related tumorigenesis in inherited and a subset of sporadic carcinoids, our array CGH data suggest several mechanisms of tumorigenesis for the nonfamiliar pulmonary carcinoids.

First, a group of tumors independent of $\mathrm{CIN}$ and $11 \mathrm{q}$ deletion demonstrates a favorable prognosis and comprised the TCs and a subset of ACs. We demonstrated that fewer alterations are present in TCs than in ACs. Combined results of the underlying and earlier studies indicate that alterations in TCs are infrequent and randomly distributed over the genome. They comprise gains of $19 q(10 \%), 20 p(10 \%), 17 q(9 \%)$, and $19 p(9 \%)$ and losses of $11 q(22 \%), 11 p(10 \%), 13 q(8 \%)$, and $6 q$ $(8 \%)^{13,16,29,30,52}$ In these cases, one might suggest involvement of processes such as epigenetic silencing of tumor-suppressor genes or deregulation of apoptosis. $^{51,53}$

Second, a subset of carcinoids with highly malignant potential demonstrates deletion of 11q22.3-q25 as the major genetic event during carcinogenesis. In these tumors, it is likely that one or more tumor-suppressor genes are inactivated on the retained arm. Two of our cases in this group, with (large) 11q deletions, also demonstrated somatic MEN1 gene mutations. In contrast to familiar MEN1-related tumors, which usually are associated with a good prognosis, these two cases demonstrated a poor disease outcome as a result of 11q22.3-q25 loss.

Third, carcinoids that exhibit extensive CIN demonstrate a variable clinical outcome. Most of these cases also harbor deletion of chromosome 11q. Most of these 
exhibit 9q34 gain and are associated with a relatively good prognosis. Here, 11q may be deleted as a consequence of $\mathrm{CIN}$, with genes on the retained $11 \mathrm{q}$ arm likely intact, resulting in a less malignant phenotype. Two patients with lung carcinoids with extensive CIN exhibited both $11 \mathrm{q}$ deletion and amplifications at other chromosomal regions, and died within 3 years after diagnosis. Our data indicate that in one of these patients, the amplification involved the proto-oncogene MYC. Amplification of MYC has not previously been reported in lung carcinoids, although they are common in high-grade neuroendocrine carcinomas such as small-cell lung cancer and large-cell neuroendocrine carcinoma. ${ }^{54}$ Because this patient demonstrated a relatively high mitotic count and the array $\mathrm{CGH}$ profile resembled that of large-cell neuroendocrine carcinoma, ${ }^{13}$ it is tempting to speculate that this tumor represented a borderline lesion between $\mathrm{AC}$ and large-cell neuroendocrine carcinoma.

In conclusion, deletion of 11q22.3-q25 rather than $11 \mathrm{q} 13$ is involved in pulmonary carcinoid tumors. This deletion is associated with ACs and lower 10-year survival, indicating the presence of genes that potentially suppress carcinoid progression in this chromosomal region. Gain in 9q34.11 was associated with a better prognosis, and a combination of 11q22.3-q25 loss and absence of 9 q34.11 gain seems to be the best predictor of unfavorable outcome with bronchial carcinoids. On the basis of these genomic alterations in combination with clinical outcome, we postulate three different mechanisms of tumorigenesis other than MEN1-related pathogenesis. In particular, assessment of 11q22.3-q25 loss may be useful in diagnosis of lung carcinoid as an indicator of poor prognosis, which may have consequences for patient management.

\section{Acknowledgments}

We thank Dr. Karoly Szuhai for providing the arrays.

\section{References}

1. Beasley MB, Thunnissen FB, Hasleton PhS, Barbareschi M, Pugatch B, Geisinger K, Brambilla E, Gazdar A, Travis WD. Carcinoid Tumour, in: Pathology and Genetics of Tumours of the Lung, Pleura, Thymus and Heart. Edited by WD Travis WD, E Brambilla, HK MullerHarmelink, Harris CC. Lyon, France, IARC Press, 2004:59-62

2. Travis WD: Advances in neuroendocrine lung tumors. Ann Oncol 2010, 21(Suppl 7):vii65-vii71

3. Granberg D, Eriksson B, Wilander E, Grimfjard P, Fjallskog ML, Oberg $\mathrm{K}$, Skogseid B: Experience in treatment of metastatic pulmonary carcinoid tumors. Ann Oncol 2001, 12:1383-1391

4. Beasley MB, Thunnissen FB, Brambilla E, Hasleton P, Steele R, Hammar SP, Colby TV, Sheppard M, Shimosato Y, Koss MN, Falk R, Travis WD: Pulmonary atypical carcinoid: predictors of survival in 106 cases. Hum Pathol 2000, 31:1255-1265

5. Lim E, Goldstraw $P$, Nicholson AG, Travis WD, Jett JR, Ferolla $P$, Bomanji J, Rusch VW, Asamura H, Skogseid B, Baudin E, Caplin M, Kwekkeboom D, Brambilla E, Crowley J: Proceedings of the IASLC International Workshop on Advances in Pulmonary Neuroendocrine Tumors 2007. J Thorac Oncol 2008, 3:1194-1201

6. Granberg D, Wilander E, Oberg K, Skogseid B: Prognostic markers in patients with typical bronchial carcinoid tumors. J Clin Endocrinol Metab 2000, 85:3425-3430
7. Brambilla E, Negoescu A, Gazzeri S, Lantuejoul S, Moro D, Brambilla C. Coll JL: Apoptosis-related factors p53, Bclll, and Bax in neuroendocrine lung tumors. Am J Pathol 1996, 149:1941-1952

8. Beasley MB, Lantuejoul S, Abbondanzo S, Chu WS, Hasleton PS, Travis WD, Brambilla E: The P16/cyclin D1/Rb pathway in neuroendocrine tumors of the lung. Hum Pathol 2003, 34:136-142

9. Lohmann DR, Fesseler B, Putz B, Reich U, Bohm J, Prauer H, Wunsch $\mathrm{PH}$, Hofler $\mathrm{H}$ : Infrequent mutations of the p53 gene in pulmonary carcinoid tumors. Cancer Res 1993, 53:5797-5801

10. Rickman OB, Vohra PK, Sanyal B, Vrana JA, Aubry MC, Wigle DA, Thomas CF: Analysis of ErbB receptors in pulmonary carcinoid tumors. Clin Cancer Res 2009, 15:3315-3324

11. Debelenko LV, Brambilla E, Agarwal SK, Swalwell JI, Kester MB, Lubensky IA, Zhuang Z, Guru SC, Manickam P, Olufemi SE, Chandrasekharappa SC, Crabtree JS, Kim YS, Heppner C, Burns AL, Spiegel AM, Marx SJ, Liotta LA, Collins FS, Travis WD, Emmert-Buck MR: Identification of MEN1 gene mutations in sporadic carcinoid tumors of the lung. Hum Mol Genet 1997, 6:2285-2290

12. Görtz B, Roth J, Krahenmann A, de Krijger RR, Muletta-Feurer $S$, Rutimann K, Saremaslani P, Speel EJ, Heitz PU, Komminoth P: Mutations and allelic deletions of the MEN1 gene are associated with a subset of sporadic endocrine pancreatic and neuroendocrine tumors and not restricted to foregut neoplasms. Am J Pathol 1999, 154:429436

13. Johnen G, Krismann M, Jaworska M, Muller KM: [CGH findings in neuroendocrine tumours of the lung]. German. Pathologe 2003, 24: 303-307

14. Petzmann S, Ullmann R, Klemen H, Renner H, Popper HH: Loss of heterozygosity on chromosome arm 11q in lung carcinoids. Hum Pathol 2001, 32:333-338

15. Petzmann S, Ullmann R, Halbwedl I, Popper HH: Analysis of chromosome-11 aberrations in pulmonary and gastrointestinal carcinoids: an array comparative genomic hybridization-based study. Virchows Arch 2004, 445:151-159

16. Walch AK, Zitzelsberger HF, Aubele MM, Mattis AE, Bauchinger M, Candidus S, Prauer HW, Werner M, Hofler H: Typical and atypical carcinoid tumors of the lung are characterized by $11 \mathrm{q}$ deletions as detected by comparative genomic hybridization. Am J Pathol 1998 , 153:1089-1098

17. Zhao J, de Krijger RR, Meier D, Speel EJ, Saremaslani P, MulettaFeurer S, Matter C, Roth J, Heitz PU, Komminoth P: Genomic alterations in well-differentiated gastrointestinal and bronchial neuroendocrine tumors (carcinoids): marked differences indicating diversity in molecular pathogenesis. Am J Pathol 2000, 157:1431-1438

18. Schussheim DH, Skarulis MC, Agarwal SK, Simonds WF, Burns AL, Spiegel AM, Marx SJ: Multiple endocrine neoplasia type 1: new clinical and basic findings. Trends Endocrinol Metab 2001, 12:173178

19. Knijnenburg J, Burg MvD, Tanke HJ, Szuhai K: Optimized amplification and fluorescent labeling of small cell samples for genomic arrayCGH. Cytometry A 2007, 71:585-591

20. Jonkers YM, Claessen SM, Feuth T, van Kessel AG, Ramaekers FC Veltman JA, Speel EJ: Novel candidate tumour suppressor gene loci on chromosomes 11q23-24 and 22q13 involved in human insulinoma tumourigenesis. J Pathol 2006, 210:450-458

21. Jonkers YM, Claessen SM, Perren A, Schmitt AM, Hofland LJ, de Herder W, de Krijger RR, Verhofstad AA, Hermus AR, Kummer JA, Skogseid B, Volante M, Voogd AC, Ramaekers FC, Speel EJ: DNA copy number status is a powerful predictor of poor survival in endocrine pancreatic tumor patients. Endocr Relat Cancer 2007, 14:769779

22. Jonkers YM, Claessen SM, Perren A, Schmid S, Komminoth P, Verhofstad AA, Hofland LJ, de Krijger RR, Slootweg PJ, Ramaekers FC Speel EJ: Chromosomal instability predicts metastatic disease in patients with insulinomas. Endocr Relat Cancer 2005, 12:435-447

23. Kent WJ, Sugnet CW, Furey TS, Roskin KM, Pringle TH, Zahler AM, Haussler D: The human genome browser at UCSC. Genome Res 2002, 12:996-1006

24. Chandrasekharappa SC, Guru SC, Manickam P, Olufemi SE, Collins FS, Emmert-Buck MR, Debelenko LV, Zhuang Z, Lubensky IA, Liotta LA, Crabtree JS, Wang Y, Roe BA, Weisemann J, Boguski MS, Agarwal SK, Kester MB, Kim YS, Heppner C, Dong Q, Spiegel AM, Burns AL, Marx SJ: Positional cloning of the gene for multiple endocrine neoplasia-type 1. Science 1997, 276:404-407 
25. van Asseldonk M, Schepens M, de Bruijn D, Janssen B, Merkx G, Geurts van Kessel A: Construction of a 350-kb sequence-ready $11 q 13$ cosmid contig encompassing the markers D11S4933 and D11S546: mapping of 11 genes and 3 tumor-associated translocation breakpoints. Genomics 2000, 66:35-42

26. Speel EJ, Herbergs J, Ramaekers FC, Hopman AH: Combined immunocytochemistry and fluorescence in situ hybridization for simultaneous tricolor detection of cell cycle, genomic, and phenotypic parameters of tumor cells. J Histochem Cytochem 1994, 42:961-966

27. Leotlela PD, Jauch A, Holtgreve-Grez H, Thakker RV: Genetics of neuroendocrine and carcinoid tumours. Endocr Relat Cancer 2003 10:437-450

28. Finkelstein SD, Hasegawa T, Colby T, Yousem SA: 11q13 allelic imbalance discriminates pulmonary carcinoids from tumorlets: a microdissection-based genotyping approach useful in clinical practice. Am J Pathol 155:633-640, 1999

29. Kim DH, Nagano Y, Choi IS, White JA, Yao JC, Rashid A: Allelic alterations in well-differentiated neuroendocrine tumors (carcinoid tumors) identified by genome-wide single nucleotide polymorphism analysis and comparison with pancreatic endocrine tumors. Genes Chromosomes Cancer 2008, 47:84-92

30. Warth A, Herpel E, Krysa S, Hoffmann H, Schnabel PA, Schirmacher $\mathrm{P}$, Mechtersheimer $\mathrm{G}$, Blaker $\mathrm{H}$ : Chromosomal instability is more frequent in metastasized than in non-metastasized pulmonary carcinoids but is not a reliable predictor of metastatic potential. Exp Mol Med 2009, 41:349-353

31. Arrigoni MG, Woolner LB, Bernatz PE: Atypical carcinoid tumors of the lung. J Thorac Cardiovasc Surg 1972, 64:413-421

32. Voortman J, Lee JH, Killian JK, Suuriniemi M, Wang Y, Lucchi M, Smith WI Jr, Meltzer P, Wang Y, Giaccone G: Array comparative genomic hybridization-based characterization of genetic alterations in pulmonary neuroendocrine tumors. Proc Natl Acad Sci USA 2010, 107:13040-13045

33. Guo C, White PS, Weiss MJ, Hogarty MD, Thompson PM, Stram DO, Gerbing R, Matthay KK, Seeger RC, Brodeur GM, Maris JM: Allelic deletion at 11q23 is common in MYCN single copy neuroblastomas. Oncogene 1999, 18:4948-4957

34. Spitz R, Hero B, Simon T, Berthold F: Loss in chromosome 11a identifies tumors with increased risk for metastatic relapses in localized and 4S neuroblastoma. Clin Cancer Res 2006, 12:3368-3373

35. Dunn JR, Panutsopulos D, Shaw MW, Heighway J, Dormer R, Salmo EN, Watson SG, Field JK, Liloglou T: METH-2 silencing and promoter hypermethylation in NSCLC. Br J Cancer 2004, 91:1149-1154

36. Tsou JA, Galler JS, Siegmund KD, Laird PW, Turla S, Cozen W, Hagen JA, Koss MN, Laird-Offringa IA: Identification of a panel of sensitive and specific DNA methylation markers for lung adenocarcinoma. Mol Cancer 2007, 6:70

37. Anglim PP, Galler JS, Koss MN, Hagen JA, Turla S, Campan M, Weisenberger DJ, Laird PW, Siegmund KD, Laird-Offringa IA: Identification of a panel of sensitive and specific DNA methylation markers for squamous cell lung cancer. Mol Cancer 2008, 7:62

38. Sellar GC, Watt KP, Rabiasz GJ, Stronach EA, Li L, Miller EP, Massie CE, Miller J, Contreras-Moreira B, Scott D, Brown I, Williams AR, Bates PA, Smyth JF, Gabra H: OPCML at 11q25 is epigenetically inactivated and has tumor-suppressor function in epithelial ovarian cancer. Nat Genet 2003, 34:337-343

39. Dannenberg H, Dinjens WN, Abbou M, Van UH, Pauw BK, Mouwen D, Mooi WJ, de Krijger RR: Frequent germ-line succinate dehydrogenase subunit $D$ gene mutations in patients with apparently sporadic parasympathetic paraganglioma. Clin Cancer Res 2002, 8:20612066

40. Ando K, Ohira M, Ozaki T, Nakagawa A, Akazawa K, Suenaga Y, Nakamura Y, Koda T, Kamijo T, Murakami Y, Nakagawara A: Expres- sion of TSLC1, a candidate tumor suppressor gene mapped to chromosome 11q23, is downregulated in unfavorable neuroblastoma without promoter hypermethylation. Int J Cancer 2008, 123: 2087-2094

41. Austen B, Skowronska A, Baker C, Powell JE, Gardiner A, Oscier D, Majid A, Dyer M, Siebert R, Taylor AM, Moss PA, Stankovic T: Mutation status of the residual ATM allele is an important determinant of the cellular response to chemotherapy and survival in patients with chronic lymphocytic leukemia containing an 11q deletion. J Clin Oncol 2007, 25:5448-5457

42. Yokoyama A, Wang Z, Wysocka J, Sanyal M, Aufiero DJ, Kitabayashi I, Herr W, Cleary ML: Leukemia proto-oncoprotein MLL forms a SET1like histone methyltransferase complex with menin to regulate Hox gene expression. Mol Cell Biol 2004, 24:5639-5649

43. Hughes CM, Rozenblatt-Rosen O, Milne TA, Copeland TD, Levine SS, Lee JC, Hayes DN, Shanmugam KS, Bhattacharjee A, Biondi CA, Kay GF, Hayward NK, Hess JL, Meyerson M: Menin associates with a trithorax family histone methyltransferase complex and with the hoxc8 locus. Mol Cell 2004, 13:587-597

44. Kottemann MC, Bale AE: Characterization of DNA damage-dependent cell cycle checkpoints in a menin-deficient model. DNA Repair (Amst) 2009, 8:944-952

45. Milne TA, Hughes CM, Lloyd R, Yang Z, Rozenblatt-Rosen O, Dou Y, Schnepp RW, Krankel C, Livolsi VA, Gibbs D, Hua X, Roeder RG, Meyerson M, Hess JL: Menin and MLL cooperatively regulate expression of cyclin-dependent kinase inhibitors. Proc Natl Acad Sci USA: 2005, 102:749-754

46. Brookman-Amissah N, Duchesnes C, Williamson MP, Wang $Q$, Ahmed A, Feneley MR, Mackay A, Freeman A, Fenwick K, Iravani M, Weber B, Ashworth A, Masters JR: Genome-wide screening for genetic changes in a matched pair of benign and prostate cancer cell lines using array CGH. Prostate Cancer Prostatic Dis 2005, 8:335343

47. Hosomi Y, Gemma A, Hosoya Y, Nara M, Okano T, Takenaka K, Yoshimura A, Koizumi K, Shimizu K, Kudoh S: Somatic mutation of the caspase-5 gene in human lung cancer. Int J Mol Med 2003, 12:443446

48. Lamkanfi M, Kalai M, Vandenabeele P: Caspase-12: an overview. Cell Death Differ 2004, 11:365-368

49. Lamkanfi M, Denecker G, Kalai M, D'hondt K, Meeus A, Declercq W, Saelens X, Vandenabeele P: INCA, a novel human caspase recruitment domain protein that inhibits interleukin-1beta generation. J Biol Chem 2004, 279:51729-51738

50. Soung YH, Jeong EG, Ahn CH, Kim SS, Song SY, Yoo NJ, Lee SH: Mutational analysis of caspase 1, 4, and 5 genes in common human cancers. Hum Pathol 2008, 39:895-900

51. Zirbes TK, Lorenzen J, Baldus SE, Moenig SP, Wolters U, Ottlik A, Thiele J, Holscher AH, Dienes HP: Apoptosis and expression of bcl-2 protein are inverse factors influencing tumour cell turnover in primary carcinoid tumours of the lung. Histopathology 1998, 33:123-128

52. Inamura K, Furuta R, Satoh Y, Shirakawa T, Okumura S, Nakagawa K, Fujiwara M, Tsuchiya E, Ishikawa $Y$ : Loss of chromosome $13 q$ is associated with malignant potential in pulmonary carcinoids. Cancer Genomics Proteomics 2006, 3:39-46

53. Chan AO, Kim SG, Bedeir A, Issa JP, Hamilton SR, Rashid A: CpG island methylation in carcinoid and pancreatic endocrine tumors. Oncogene 2003, 22:924-934

54. Peng WX, Shibata $T$, Katoh H, Kokubu A, Matsuno $Y$, Asamura $H$, Tsuchiya R, Kanai Y, Hosoda F, Sakiyama T, Ohki M, Imoto I, Inazawa J, Hirohashi S: Array-based comparative genomic hybridization analysis of high-grade neuroendocrine tumors of the lung. Cancer Sci 2005, 96:661-667 